\title{
GROUP DYNAMIC IMPACT ON QUALITY OF THE PROJECTS IN PHARMACUTICAL INDISTRY
}

Eldabaa, N. ${ }^{(1)}$; EL Seddawy, A. B..$^{(2)}$ and Mohamed, H. A. ${ }^{(3)}$ 1) Faculty of Education, Ain Shams University 2) The Arab Academy for Science, Technology and Maritime Transport (AASTMT) 3) Productivity and Quality Institute (PQI), the Arab Academy for Science, Technology and Maritime Transport (AASTMT)

\begin{abstract}
Group dynamic and project management are both considered as a part of the business excellence, these techniques have already been implemented successfully in several areas of manufacturing business in the last decades. In particular, they have been implemented in service entities as well as manufacturing companies due to their improvement on costs reduction, delivery on time and quality service.

Pharmaceutical Industry role as a pharmaceutical embedded in a corporation that manufactures building materials, places it in a position to draw on optimization techniques from arenas of industry, it has become noticeable recently, that the team creating with increasing leadership skills and techniques by save the time and good communication skills simultaneously, a big variation on the analysis time which is not complying with the best practices from the equivalent pharmaceutical industries.

This thesis discusses the successful tools and practices as well as the challenges with implementation of group dynamic integrated with project management techniques by following the project management and group dynamic methodology; using the appropriate tools in each phase, the progress of the project was accelerated to meet the proposed goals and objectives in a practical manner.

The theoretical background is achieved through exploring the literature of group dynamic, team building and project management. The development will be done in collaboration with the related stakeholders, by following the group dynamic improvement process and by analyzing the process survey data from the target company.
\end{abstract}


The project resumed by using appropriate systemic tool to build and implement any project and proves the processes improvement and the potential net profit.

Thus, Group dynamic methodology was found to be an effective problem solving approach if used parallel with project management methodology and the systematic use of the proposed integrated approach can ensure savings in terms of time and money.

Key Words: Group Dynamic, Project Management, Team Building, Quality Assurance, Minitab.

\section{INTRODUCTION}

The term "team building" has become a buzzword in recent years, and has many connotations. In terms of corporate development, team-building exercises are important not for the immediate experience of the activities performed by the team, but also for the group skills, communication and bonding that result. The main goals of team-building are to improve productivity and motivation.

Taking employees out of the office helps groups break down political and personal barriers, eliminate distractions.

The benefits of team-building programs are so significant that many corporations have incorporated teambuilding strategies into their standard training curriculum.

Team building is very important if you wish to extract the best out of your workforce. Employees are urged to work smarter and not just harder, in an effort to deliver the desired results. Though it definitely contributes in its own way, individual brilliance does not singlehandedly decide the fate of an entire project. Almost always, it is the joint efforts (or the lack thereof) of the whole team that eventually decide the success or failure of a project. In such 
cases, team building in the workplace becomes absolutely essential for a number of reasons.

Team building in an office helps to foster better and open communication between the employees themselves, as well as between the employees and the higher management. It goes a long way in improving professional relations, understanding and co-operation, and this is very much reflected in the quality of work being done. Team building in the workplace significantly contributes towards employee motivation and building trust among the employees, thereby ensuring better productivity.

In an attempt to find relevant information for this thesis, the literature review chapter will give basic information about the group dynamic, team building methodology, Stage of Team building, team development, its principles and historical developments of the group dynamic, Group development and the relationship between group dynamic and quality.

\section{Part 1:}

1) The Meanings of "Group/Group dynamic: Group dynamics is a system of behaviors and psychological processes occurring within a social group (intragroup dynamics), or between social groups (intergroup dynamics). The study of group dynamics can be useful in understanding decision-making behavior, tracking the spread of diseases in society, creating effective therapy techniques, and following the emergence and popularity of new ideas and technologies. Group dynamics are at the core of understanding racism, sexism, and other forms of social prejudice and discrimination. These applications of the field are studied in psychology, sociology, anthropology, 
political science, epidemiology, education, social work, business, and communication studies.

A group is two or more individuals who are connected by and within social relationships. A group can range in size from two members to thousands of members. A very small collective, such as dyads (two members) and triads (three members) are grouping (Forsyth, Group dynamic, Mar 19.2009)

Definitions of the group vary, but many stress one key consideration relationships among the members. Thus "a group is a collection of individuals who have relations to one another" (Zander, 1968)P.46; "a group is a social unit which consists of a number of individuals who stand in (more or less) definite status and role relationships to one another" (Ashford, 2010.2008); and a group is "a bounded set of patterned relations among members" (Holly Arrow, 2000)

Group dynamic describes both a subject matter and a scientific field of study. When Kurt Lewin (1951) described the way groups and individuals act and react to Changing circumstances, he named these processes group dynamic (Lwin, 1951). But Lewin also used the phrase to describe the scientific discipline devoted to the study of these dynamics.

The first scientific studies of groups were not carried out until the 1900s. (Forsyth, Group dynamic , 1900)

Group work has emerged as a strategic curriculum response among business educators attempting to come to terms with an entrenched industry, enterprise and graduate focus on teamwork. The fact that organizations have 
continuously moved toward an internal structure based on work teams or groups has not escaped the focus of management educators. This is manifest in a curriculum focus that treats (as routine) aspects of socio-technical work design, quality circles, TQM and their corresponding models of human and intellectual capital. The workplace is no longer the frontier of individual achievement for the 'top gun' graduate, but is painted more as a 'networked' environment peopled by graduates with the skills to work in a team setting. (Langrfred, 2007)

Group dynamics is a system of behaviors and psychological processes occurring within a social group (intragroup dynamics), or between social groups (intergroup dynamics). The study of group dynamics can be useful in understanding decision-making behavior, tracking the spread of diseases in society, creating effective therapy techniques, and following the emergence and popularity of new ideas and technologies (Backstrom, Huttenenlocher, Kleinberg, \& Lan, 2006).

The history of group dynamics (or group processes) has a consistent, underlying premise: 'the whole is greater than the sum of its parts. (Hogg, June 2004).

A social group is an entity, which has qualities that cannot be understood just by studying the individuals that make up the group. In 1924, Gestalt psychologist, Max Wertheimer identified this fact, stating 'There are entities where the behavior of the whole cannot be derived from its individual elements nor from the way these elements fit together; rather the opposite is true: the properties of any of the parts are determined by the intrinsic structural laws of the whole' (Westheimer, 1998) 
As a field of study, group dynamics has roots in both psychology and sociology. Wilhelm Wundt (1832-1920), credited as the founder of experimental psychology, had a particular interest in the psychology of communities, which he believed possessed phenomena (human language, customs, and religion) that could not be described through a study of the individual. (Hogg, June 2004)

On the sociological side, Émile Durkheim (1858-1917), who was influenced by Wundt, also recognized collective phenomena, such as public knowledge. Other key theorists include Gustave Le Bon (1841-1931) who believed that crowds possessed a 'racial unconscious' with primitive, aggressive, and antisocial instincts, and William McDougall (psychologist), who believed in a 'group mind,' which had a distinct existence born from the interaction of individuals. (Hogg, June 2004)

\section{2-Group Theorists:}

1) Gustave Le Bon: Gustave Le Bon was a French social psychologist whose seminal study, The Crowd: A Study of the Popular Mind (1896) led to the development of group psychology. (Sadava, 2014)

2)William McDougall: The British psychologist William McDougall in his work The Group Mind (1920) researched the dynamics of groups of various sizes and degrees of organization.

3) Sigmund Freud: In Group Psychology and the Analysis of the Ego, (1922), Sigmund Freud based his preliminary description of group psychology on Le Bon's work, but went on to develop his own, original theory, related to what he had begun to elaborate in Totem and Taboo. 
Theodor Adorno reprised Freud's essay in 1951 with his Freudian Theory and the Pattern of Fascist Propaganda, and said that "It is not an overstatement if we say that Freud, though he was hardly interested in the political phase of the problem, clearly foresaw the rise and nature of fascist mass movements in purely psychological categories."

4) Jacob L. Moreno: Jacob L. Moreno was a psychiatrist, dramatist, philosopher and theoretician who coined the term "group psychotherapy" in the early 1930s and was highly influential at the time.

5) Kurt Lewin: Kurt Lewin (1943, 1948, and 1951) is commonly identified as the founder of the movement to study groups scientifically. He coined the term group dynamics to describe the way groups and individuals act and react to changing circumstances. Group dynamics can be defined as a field of enquiry dedicated to the advancing knowledge about the nature of groups, the laws of their development and their interrelations with individuals, other groups and larger institutions. Based on their feelings and emotions, members of a group form a common perception. The interactive psychological relationship in which members of a group form this common perception is actually "Group Dynamics".

The phrase "Group Dynamics" contains two words- (i) Group- a social unit of two or more individuals who have in common a set of beliefs and values, follow the same norms and works for an establish able common aim. The members of the group share a set of common purpose, tasks or goals. (ii) Dynamics- the flow of, coherent activities which as envisaged, will lead the group towards the establishment of its set goals. 
6) William Schutz: William Schutz (1958, 1966) looked at interpersonal relations from the perspective of three dimensions: inclusion, control, and affection. This became the basis for a theory of group behavior that sees groups as resolving issues in each of these stages in order to be able to develop to the next stage. Conversely, a group may also devolve to an earlier stage if unable to resolve outstanding issues in a particular stage. He referred to these group dynamics as "the interpersonal underworld" because they dealt with group processes that were largely unseen, as opposed to "content" issues, which were nominally the agenda of group meetings.

7) Wilfred Bion: Wilfred Bion (1961) studied group dynamics from a psychoanalytic perspective, and stated that he was much influenced by Wilfred Trotter for whom he worked at University College Hospital London, as did another key figure in the Psychoanalytic movement, Ernest Jones. He discovered several mass group processes which involved the group as a whole adopting an orientation which, in his opinion, interfered with the ability of a group to accomplish the work it was nominally engaged in his experiences are reported in his published books, especially Experiences in Groups. (Irvin D. Yalom, 2005)

8) Bruce Tuckman: Bruce Tuckman (1965) proposed the four-stage model called Tuckman's Stages for a group.

Forming (pretending to get on or get along with others)

Storming (letting down the politeness barrier and trying to get down to the issues even if tempers flare up) Norming (getting used to each other and developing trust and productivity) 
Performing (working in a group to a common goal on a highly efficient and cooperative basis)

9) M. Scott Peck: M. Scott Peck developed stages for larger-scale groups (i.e., communities) which are similar to Tuckman's stages of group development. (M. Scott Peck, 1987).

3-Team Building Definitions: "Team building is the process of helping a work group become more effective in accomplishing its tasks and in satisfying the needs of group members." (Eden, 1985)

"Team building is a process by which members of a group diagnose how they work together and plan changes which will improve their effectiveness." (Team Building through Mutual Sharing and Open Discussion of Team Functioning, 2009)(Beer, 1980, p. 140)

In 1980 an estimated 250 worksites used teams; by 1988 it had increased to $67 \%$ and by 1990 to $83 \%$. Nearly all workplaces have introduced teams to some degree at this time; $80 \%$ of Fortune 500 companies have half their employees working in teams.

$56 \%$ of large companies with over 5,000 employees use virtual teams; Industry Week reports that $68 \%$ of small companies use teams, with over $25 \%$ having $25-99 \%$ of employees in teams.

Many team building exercises are intended to find and address interpersonal problems within the group. (Salas E. D., 2008)

According to Klein et al. (2009), team building is one of the most widely used group development activities in organizations. 
Team building in organizations is a common approach to achieving organizational or departmental results, in fun and non-threatening environments.

Employee engagement exercises allow teams to create solutions that are meaningful to them, with direct impact on the individuals, the team, and the organizational objectives.

Team building activities that are competitive in nature allow teams to own their actions by producing meaningful results. The alternative approach is collaborative team building activities where teams must come together and act as one unit to produce results. The ideal is to designing team building activities that encompass both competitive and collaborative themes.

At the organizational level, team building is a philosophy of job design in which employees are viewed as members of interdependent teams instead of as individual workers. (Fapohunda, 2013)"Team building in sport: a narrative review of the program effectiveness, current methods, and theoretical underpinnings)

\section{Part 2:}

\section{1). Research Model:}

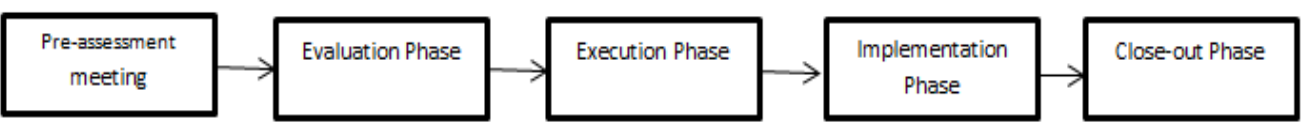

Figure(1): System of Cohesion Group

1.2 Survey Objective: Group dynamics play an important role in Pharmaceutical industries. All of the existing projects at pharmaceutical methodologies use the concept of the teamwork and emphasize the 90 Vol. 36, No.3, Dec. 2016 
necessity to manage them in order to organize the business processes in the best way. The application of group dynamic techniques is aimed at improvement of teamwork management to make it more efficient. The implementation of group dynamic techniques has an impact on teams working in Pharmaceutical industries and it also faces some challenges for industry such as lack of resources and preparation. Both need additional investigation which regard to the actual practiced situation in industry.

Work is devoted to identification of group dynamics techniques and their impact on teams in the context of industrial development projects. The objectives of the research is to identify the existing and in an industrial context, actually used group dynamics techniques in Pharmaceutical industries as well as their impact and methods of its evaluation. Since the application of group dynamics techniques is not a trivial task, we also identify those challenges and corresponding mitigation strategies.

The basic methods applied during the research conduction are systematic literature review and survey. Literature review was used in order to collect the data on group dynamics techniques, their impact and implementation challenges. The survey and additional interviews with the practitioners from the pharmaceuticals companies were done with the purpose to find out which of the techniques are applied in practice. 
Based on the data from systematic literature review we identified group dynamics techniques such as equalizing participation, electronic communication, conflict resolution, summarizing, whole and small group discussions, brainstorming, etc. The discovered impacts include team performance and cohesiveness, staff satisfaction and communication quality, software quality, reasonable decision-making and knowledge sharing. The possible challenges of group dynamics techniques implementation are company's limited resources, lack of leadership and preparation, overdominating of some team members and cultural diversity. The survey provided us with additional information about the importance of mentioned group dynamics techniques and their impact on team performance and cohesiveness, job satisfaction and software quality.

People are the most important resource of any enterprise. The success of any business project directly depends on the members of the team, involved in the development process (R. M. Verburg, 2013). Team members are the intellectual capital of any organization. Managing these resources requires some special knowledge and training. The efficient management determines the success of project's execution.

Project management often deals with groups of people who have to perform some job like for example, requirements specification, software design, construction and testing. People often work in teams (Forsyth, 2010). Primarily, project management is explained by the complexity and comprehensive structure of the projects. A complicated project consisting of several tasks cannot be implemented by a single person and even if it could 
be realized, it would take too much time for completion. So the natural solution of this problem is to organize the team of people, who can perform the necessary volume of work in a shorter time. In this situation a project manager faces with the problem of managing the group work.

The concept of group has several aspects of definition. A group can be considered as two or more individuals who are connected by and within social relationships (R. M. Verburg, 2013). Such definition emphasizes the importance of communications between group members and the key role played by mutual dependencies within the group. Lewin K. called the processes of how groups and individuals act and react to changing circumstances group dynamics (R. M. Verburg, 2013). Group dynamics considers different aspects of group members' interaction.

The studies related to group dynamics techniques pay much attention to the description of the techniques and on the analysis of their impact on teams working in Pharmaceutical Industries. Another point is that authors rarely discuss the influence of team size and structure on the selection of implemented techniques and their impact. The goal of this work is to explore existing work on group dynamics from literature and also in practice especially well as their impacts on teams working in Pharmaceutical Industries.

Survey and additional interviews should be conducted to identify the impact of the techniques that are used in the industry.

Once the group dynamics techniques and their impact on teams are investigated through survey, a survey plus interviews can be conducted in order to validate to what extent these group dynamics techniques are actually 
implemented in industry and also to investigate if they have an impact on improving the overall performance of the project

Survey was chosen as a research method, because it provides the appropriate way to collect responses from pharmaceutical industries members from multinational industries as one of our goals is to get to know the actual situation regarding team building in industry.

Preliminary Questions to test the background of applying group dynamic strategy for build groups for work with high quality output:

Table(1): Preliminary Questions

\begin{tabular}{|c|l|c|c|c|}
\hline \multirow{2}{*}{ No. } & \multicolumn{1}{|c|}{ Q. Criteria } & \multicolumn{3}{|c|}{ Answers } \\
\cline { 3 - 5 } & \multicolumn{1}{|c|}{ Yes } & Partially & No \\
\hline \hline 1 & Is the methodology clearly? & 80 & 45 & 0 \\
\hline 2 & $\begin{array}{l}\text { Is the methodology appropriate for the } \\
\text { given type of research? }\end{array}$ & 100 & 25 & 0 \\
\hline 3 & $\begin{array}{l}\text { Are you ready to apply group dynamic } \\
\text { Form to get sold teams in your area? }\end{array}$ & 77 & 48 & 0 \\
\hline
\end{tabular}

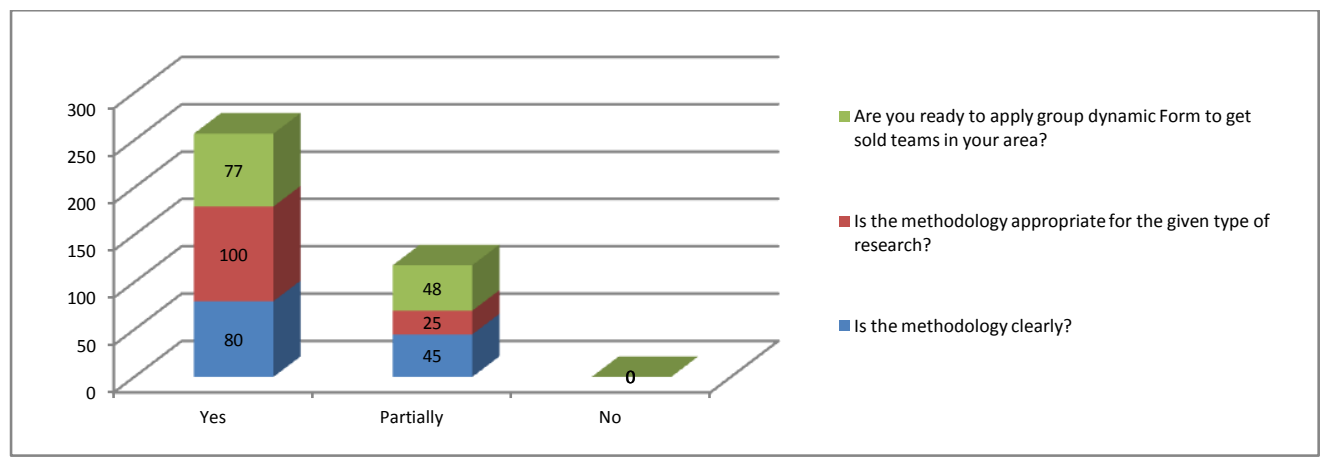

Figure(2): Chart of Preliminary Questions 
$80 \%$ of primary studies describe the applied methodology in details. The Preliminary research results are (most have got both answers "Yes" and "Partially" for the questions). Generally, the quality of all primary studies can be estimated positively, so their investigation would give the reliable results.

The survey, from start to finish, is an opportunity for raising awareness. The measures of the mid-decade goal indicators should be used to reinforce group dynamic concept and implementation procedure at all levels, to redirect or make corrective adjustments to system to applying the group dynamic concept on systematic way by taking action plan where necessary and to help policy makers take action that will build and sustain system. That is why it is necessary to use the survey results to the fullest extent, building on the plans made in the early stages of survey planning.

Surveys were developed in close coordination according to Preliminary assessment for the background of knowledge about the group dynamic concepts to ensure that questions covered topics of interest based on current knowledge and anecdotal evidence.

The system generated from survey output and factors gained from fishbone diagram; to provide a system handling group building by group dynamic. This procedure is for any case of build a group for specific project or task.

The objective of this chapter is to ensure any project move in systematic way which could have an effect on good practices, quality, and healthy environment protection. 
Adherence to the plan or the system movement to ensure that the project is suitably occurred and implemented and documented by competent personnel. Necessary actions related to the project must be properly followed up.

This procedure ensures compliance by controlling all project related and registration relevant information. Reduce transparency and traceability in to single source or system platform and be close loop process.

Launch site confirmation; Trigger for launch related group building activities is the launch site decision, which defines the processes and the responsibility.

\section{Group Building system Procedure:}

Question 1: For the first Question "characteristics of an effective group"

There are four factors affect for the effective group as per survey point of view:

Table (2): Characteristics of an effective group

\begin{tabular}{|c|c|c|c|c|}
\hline $\begin{array}{c}\text { Characteristi } \\
\text { c } \\
\text { Rate }\end{array}$ & $\begin{array}{c}\text { Every } \\
\text { member } \\
\text { knows the } \\
\text { group's } \\
\text { goal(A) }\end{array}$ & $\begin{array}{c}\text { Brainstorming and } \\
\text { selecting the } \\
\text { homogenous thinking } \\
\text { members is important } \\
\text { to get success team(B) }\end{array}$ & $\begin{array}{c}\text { Each member } \\
\text { is clear about } \\
\text { their role and } \\
\text { responsibilities } \\
\text { (C) }\end{array}$ & $\begin{array}{c}\text { Members of } \\
\text { the group } \\
\text { know what } \\
\text { is expected } \\
\text { of them(D) }\end{array}$ \\
\hline $\begin{array}{c}\text { No. of } \\
\text { voices }\end{array}$ & 100 & 87 & 95 & 120 \\
\hline Present \% & $80 \%$ & $69.9 \%$ & $76 \%$ & $96 \%$ \\
\hline
\end{tabular}




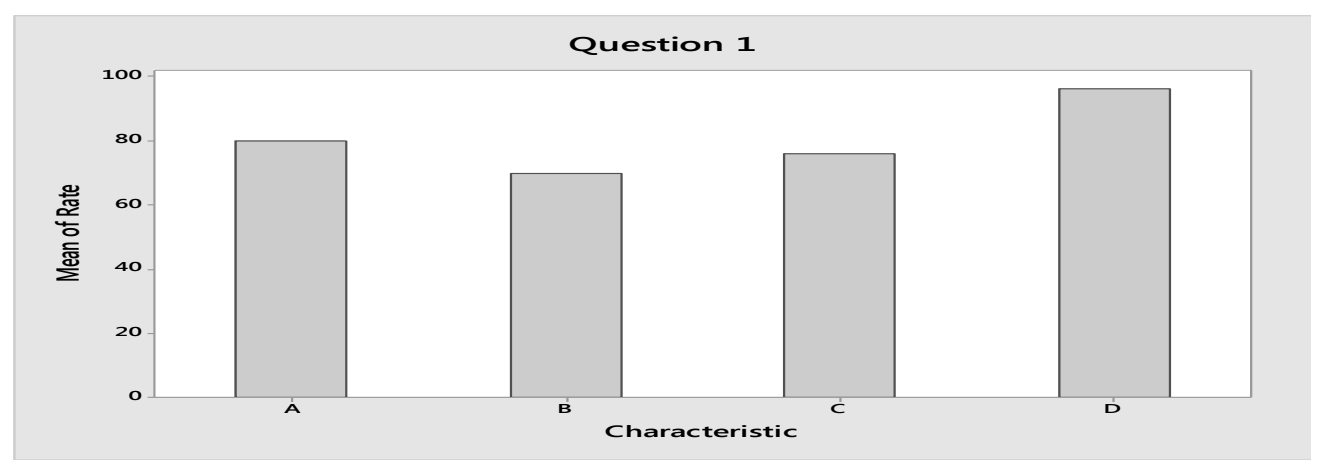

Figure(3): The most affected factors and characteristics for good team Q 1

Question 2: "Effect of personality on the group building"

This Question target the personality of work and the how this factor interact with the outcome to get a good team.

Table(3): Effect of Personality on the group dynamic Q3

\begin{tabular}{|c|c|c|c|}
\hline $\begin{array}{c}\text { Personality } \\
\text { Rate }\end{array}$ & $\begin{array}{c}\text { The Personality } \\
\text { only effect on the } \\
\text { group(A) }\end{array}$ & $\begin{array}{c}\text { Personality has } \\
\text { no influence in } \\
\text { groups(B) }\end{array}$ & $\begin{array}{c}\text { Personality and } \\
\text { situation interact to } \\
\text { affect behavior in } \\
\text { group(C) }\end{array}$ \\
\hline No. of voices & 59 & 2 & 63 \\
\hline Percentage $\%$ & $47.2 \%$ & $1.6 \%$ & $50.4 \%$ \\
\hline
\end{tabular}

This question get the information that the personality effect on the group either the pure personality or by affecting with the situation thus we when need to get a new group need to check this point by follow up the group outcome through phase review. 
J. Environ. Sci.

Institute of Environmental Studies and Research - Ain Shams University

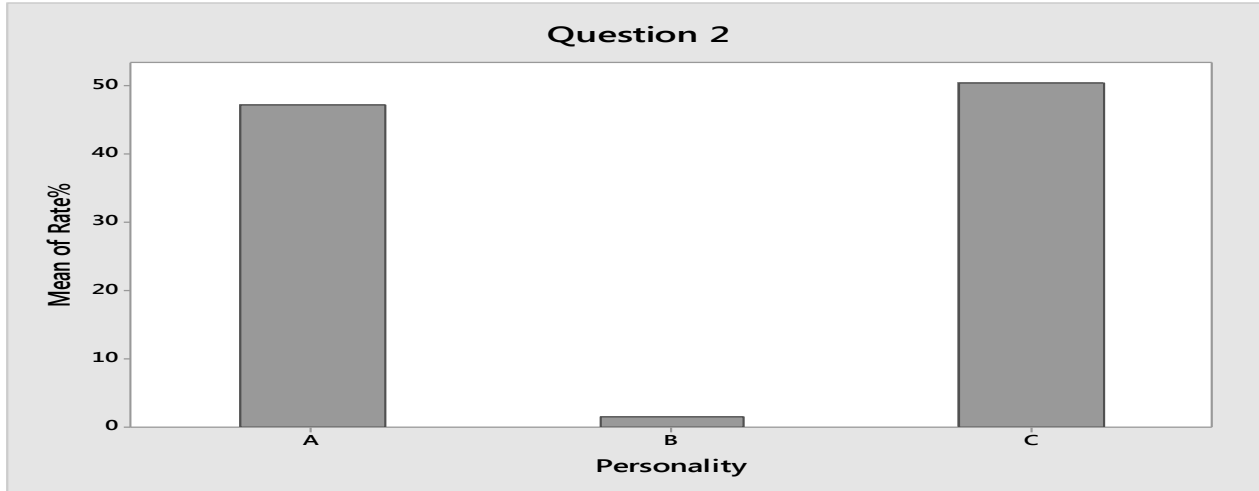

Figure (4): Personality effect on a good team Q 2

Question 3: "Role discerption"

This question descripts the importance of role description and timeline regarding the each stockholder regarding the project or the task.

Table (4): Identify the group Goals

\begin{tabular}{|c|c|c|}
\hline $\begin{array}{c}\text { Personality } \\
\text { Rate }\end{array}$ & $\begin{array}{c}\text { Individuals can have } \\
\text { formal and informal } \\
\text { roles within the group(A) }\end{array}$ & $\begin{array}{c}\text { The only important role are } \\
\text { the formal once assigned by } \\
\text { the group(B) }\end{array}$ \\
\hline No. of voices & 100 & 25 \\
\hline Percentage \% & $80 \%$ & $20 \%$ \\
\hline
\end{tabular}

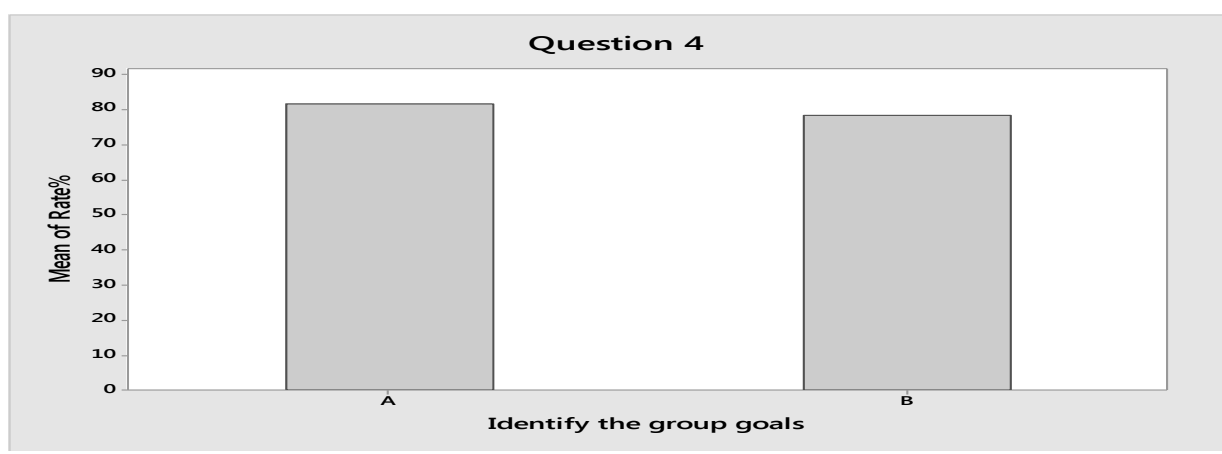

Figure (5): Importance of Identify the group goal Q 4 
Question 5: "Discuss expectations during the group's first meeting"

The output from this question is just the group is generated and collected prework meeting must be held to identify each stockholders role and the expectation form this group and how to harmonize the states of the project by dealing with any case can be handled to get at final result accurate and precise results by high quality

Table(5): Group's first meeting impact

\begin{tabular}{|c|c|c|c|}
\hline $\begin{array}{c}\text { Per - work } \\
\text { meeting } \\
\text { Rate }\end{array}$ & $\begin{array}{c}\text { Yes - It helps the } \\
\text { group to get all } \\
\text { conflict out of the } \\
\text { way early(A) }\end{array}$ & $\begin{array}{c}\text { Yes - It can help } \\
\text { the group avoid } \\
\text { conflict later(B) }\end{array}$ & $\begin{array}{c}\text { No-they should } \\
\text { not have the } \\
\text { discussion(C) }\end{array}$ \\
\hline No. of voices & 116 & 98 & 3 \\
\hline Percentage $\%$ & $92.8 \%$ & $78.4 \%$ & $2.4 \%$ \\
\hline
\end{tabular}

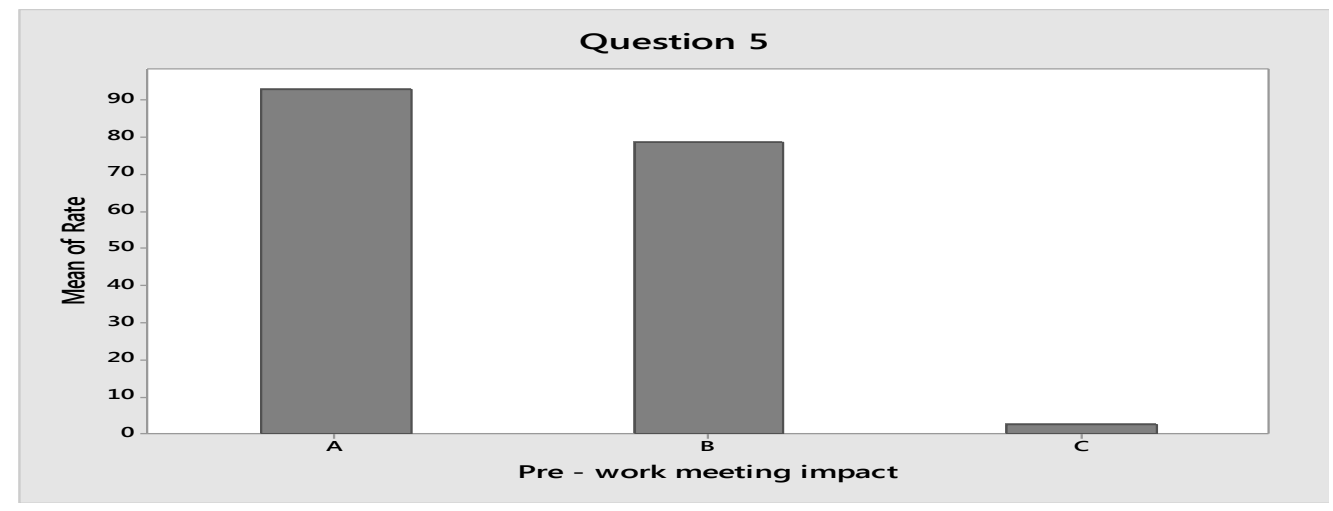

Figure (6): Pre-work meeting impact on group goal Q 5

Question 6 - 21: The following question for the survey is determined the mind site of the members that including and joining the group by select from strongly agree, agree, neutral, disagree and strongly disagree. And the aim from these questions is to get an overall vision to be able to generate the form 
J. Environ. Sci.

Institute of Environmental Studies and Research - Ain Shams University

or systematic way to contain the group and identify the key elements can be used within the system or the group form.

Table(6): Summary for From Question 6-21

\begin{tabular}{|c|c|c|c|c|c|}
\hline Description & $\begin{array}{c}\begin{array}{c}\text { Strongly } \\
\text { agree }\end{array} \\
\end{array}$ & Agree & Neutral & Disagree & $\begin{array}{l}\text { Strongly } \\
\text { disagree }\end{array}$ \\
\hline $\begin{array}{l}\text { Make a pre-work assessment FRM is } \\
\text { help to get high-quality work. }\end{array}$ & $120(96 \%)$ & $5(4 \%)$ & $0(0 \%)$ & $0(0 \%)$ & $0(0 \%)$ \\
\hline $\begin{array}{l}\text { Making sure that everyone in the } \\
\text { group understands important } \\
\text { information }\end{array}$ & $100(80 \%)$ & $\begin{array}{c}13 \\
(10.4 \%)\end{array}$ & $12(9.6 \%)$ & $0(0 \%)$ & $0(0 \%)$ \\
\hline $\begin{array}{c}\text { The provide encouragement to } \\
\text { between group members is the } \\
\text { important factor to build a good } \\
\text { team. }\end{array}$ & $84(67.2 \%)$ & $\begin{array}{c}23 \\
(18.4 \%)\end{array}$ & $\begin{array}{c}13 \\
(10.4 \%)\end{array}$ & $5(4 \%)$ & $0(0 \%)$ \\
\hline $\begin{array}{l}\text { Describe the responsibilities to the } \\
\text { group is the vital factor to success } \\
\text { the group team mission }\end{array}$ & $\begin{array}{c}113 \\
(90.4 \%)\end{array}$ & $10(8 \%)$ & $2(1.6 \%)$ & $0(0 \%)$ & $0(0 \%)$ \\
\hline $\begin{array}{l}\text { Get group input on important } \\
\text { matters before going ahead. }\end{array}$ & $97(77.6 \%)$ & $\begin{array}{c}13 \\
(10.4 \%)\end{array}$ & $15(12 \%)$ & $0(0 \%)$ & $0(0 \%)$ \\
\hline Complete work in a timely manner & $\begin{array}{c}123 \\
(98.4 \%)\end{array}$ & $2(1.6 \%)$ & O $(0 \%)$ & $0(0 \%)$ & $0(0 \%)$ \\
\hline $\begin{array}{c}\text { Feel a real sense of personal } \\
\text { satisfaction when the group does } \\
\text { well. }\end{array}$ & $78(62.4 \%)$ & $12(9.6 \%)$ & $35(28 \%)$ & $0(0 \%)$ & $0(0 \%)$ \\
\hline $\begin{array}{l}\text { Do you think it is important for } \\
\text { group members to discuss the } \\
\text { assignment with each other? }\end{array}$ & $\begin{array}{c}104 \\
(83.2 \%)\end{array}$ & $\begin{array}{c}16 \\
(12.8 \%)\end{array}$ & $5(4 \%)$ & $0(0 \%)$ & $0(0 \%)$ \\
\hline $\begin{array}{l}\text { Think it is important for group } \\
\text { members to feel free to offer an } \\
\text { opinion regarding work-related } \\
\text { issues. }\end{array}$ & $67(53.6 \%)$ & $35(28 \%)$ & $\begin{array}{c}14 \\
(11.2 \%)\end{array}$ & $5(4 \%)$ & $4(3.2 \%)$ \\
\hline $\begin{array}{l}\text { Feel like the workload is usually less } \\
\text { if I were working alone. }\end{array}$ & $125(100 \%)$ & $0(0 \%)$ & $0(0 \%)$ & $0(0 \%)$ & $0(0 \%)$ \\
\hline $\begin{array}{l}\text { Take every group member's ideas } \\
\text { seriously is important factor for } \\
\text { team building }\end{array}$ & $99(79.2 \%)$ & $11(8.8 \%)$ & $15(12 \%)$ & $0(0 \%)$ & $0(0 \%)$ \\
\hline $\begin{array}{l}\text { Do you think it is important for } \\
\text { group members to take the time to } \\
\text { listen to problems and worries of } \\
\text { other group members }\end{array}$ & $55(44 \%)$ & $35(28 \%)$ & $20(16 \%)$ & $3(2.4 \%)$ & $12(9.6 \%)$ \\
\hline $\begin{array}{l}\text { Making sure for group members } \\
\text { have a highly homogenous for } \\
\text { thinking is have a great value for } \\
\text { success the team }\end{array}$ & $\begin{array}{c}121 \\
(96.8 \%)\end{array}$ & $4(3.2 \%)$ & $0(0 \%)$ & $0(0 \%)$ & $0(0 \%)$ \\
\hline $\begin{array}{l}\text { Pre-work meetings prepared have an } \\
\text { large value to identify the stockholders } \\
\text { and create the plan for work }\end{array}$ & $\begin{array}{c}123 \\
(98.4 \%)\end{array}$ & $2(1.6 \%)$ & $0(0 \%)$ & $0(0 \%)$ & $0(0 \%)$ \\
\hline $\begin{array}{l}\text { Share the ideas is highly Impact } \\
\text { factor for build the group. }\end{array}$ & $\begin{array}{c}111 \\
(88.8 \%)\end{array}$ & $9(7.2 \%)$ & $5(4 \%)$ & 0 (0\%) & $0(0 \%)$ \\
\hline $\begin{array}{l}\text { Do a fair share of the group's work } \\
\text { in case of uncomfortable team }\end{array}$ & $67(53.6 \%)$ & $\begin{array}{c}36 \\
(28.8 \%)\end{array}$ & $\begin{array}{c}22 \\
(17.6 \%)\end{array}$ & $0(0 \%)$ & $0(0 \%)$ \\
\hline
\end{tabular}


Make a pre-work assessment FRM is help to get high-quality work:

After review the question survey from 6-21 some point can be extract; $96 \%$ from the members undergo of survey have a strongly agree for importance regarding to pre-work assessment as an initial step creating and build the team which this meeting or pre-work assessment has to be done before the any project to proceed and initiate the project and set of the objectives.

Make a pre-work assessment FRM is help to get high-quality work

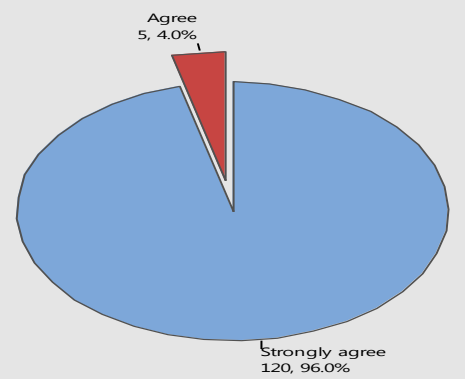

Figure (7): Pre-work assessment \% of need

Making sure that everyone in the group understands important information $80 \%$ strongly agree $10.4 \%$ agree from the members undergo for that must be making sure that everyone in the group understands important information as what is the current state for the project or the task and what is expected and proposed change for the task or the project 
Making sure that everyone in the group understands important information
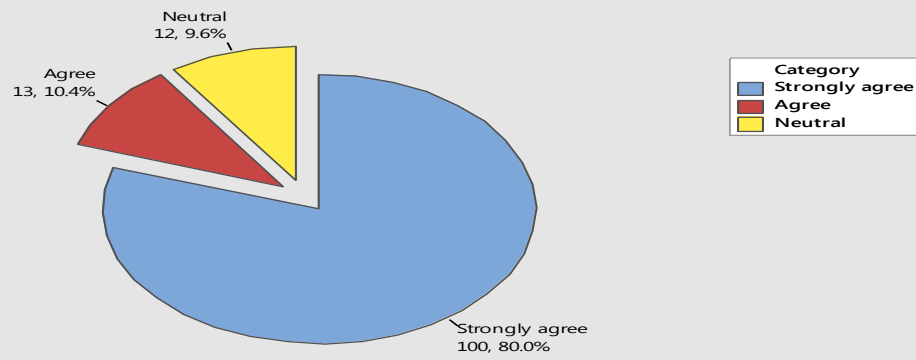

Figure(8): understanding all information regarding the project

The provide encouragement to between group members is the important factor to build a good team $67.2 \%$ strongly agree, $18.4 \%$ agree for that the encouragement between the group is important factor for team success and this point appeared during the interviewing the member that every team must be have an manager or team coach to follow up the progress of the project working out and can do as encouragement after each millstone checking point.

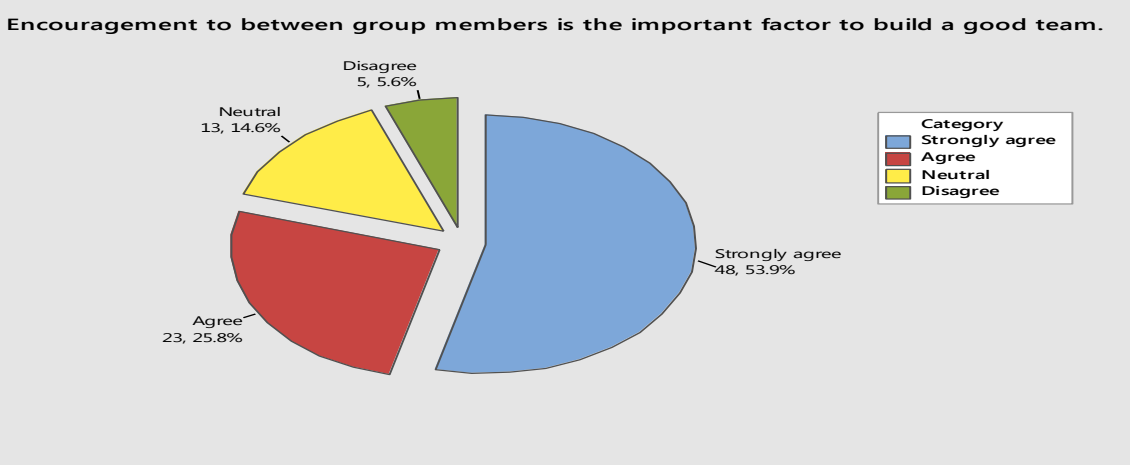

Figure (9): Encouragement Effect on Team Robustness 
Describe the responsibilities to the group is the vital factor to success the group team mission $90.4 \%$ strongly agree, $10.0 \%$ agree for the describing the responsibility for each member of the team is a vital factor to success the group. These responsibilities is detected by the team coach according to the job profile and job description; also must be tack in consideration each member strength and weaknesses and haw to use it as a part from leadership skills.

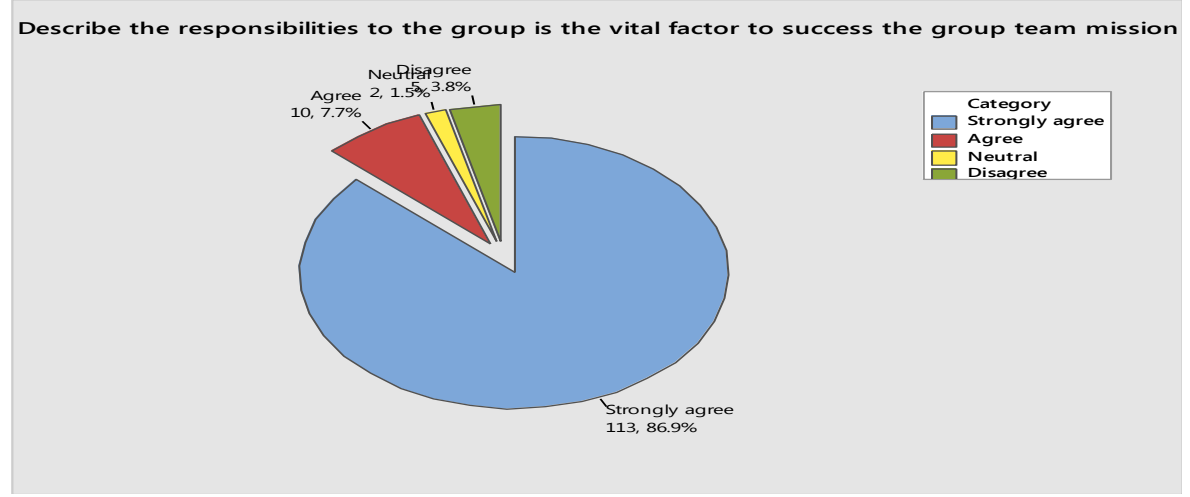

Figure (10): Description of responsibility is a vital factor

Complete work in a timely manner: $98.4 \%$ strongly agree and $1.6 \%$ agree that the time factor is one of the important factor to success the group which during the interview with the member undergo survey finding that the good planning and make a schedule time for each task must be detected and for the other side all members must be follow the time in schedule date and compare it between the actual date and from the coach point of view must have an buffer time for applying the tasks and in case the member not follow the due date; the member of the group must be justify the root cause for this delay and how to mitigate it to prevent the recurrence. 


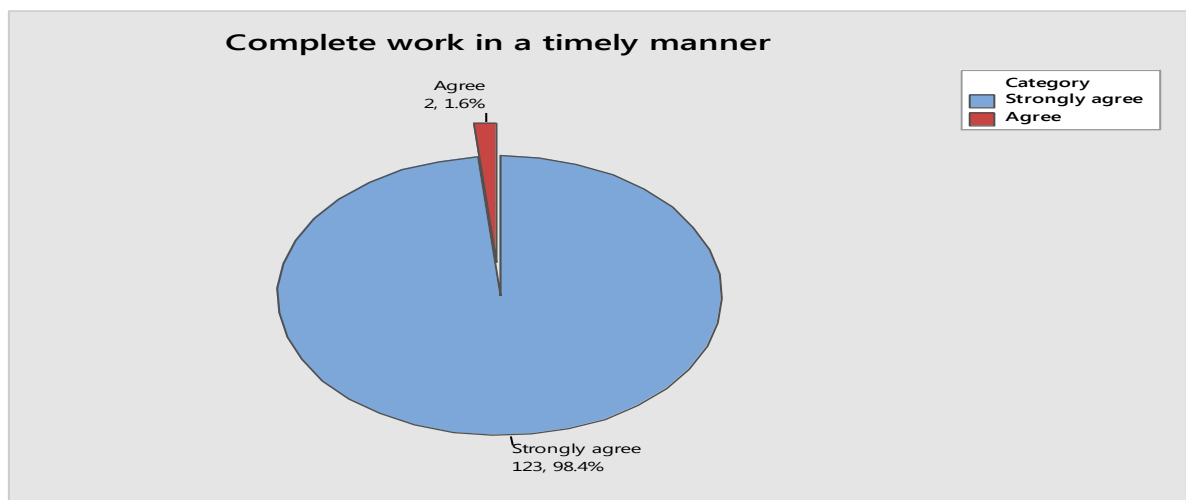

Figure (11): Time schedule factor

Feel a real sense of personal satisfaction when the group does well.

$62.4 \%$ strongly agree, $9.6 \%$ agree and $35 \%$ neutral for the personal satisfaction when the group does well, which this gap due to the lack of dynamic link between the group member as there is no role responsibility defined and to get the satisfaction there are must play as one team with one objective and goal and this objective not be able to do unless the group know every member have a number of tasks and these tasks is prerequisite for each other to get at final the group scope.

Feel a real sense of personal satisfaction when the group does well

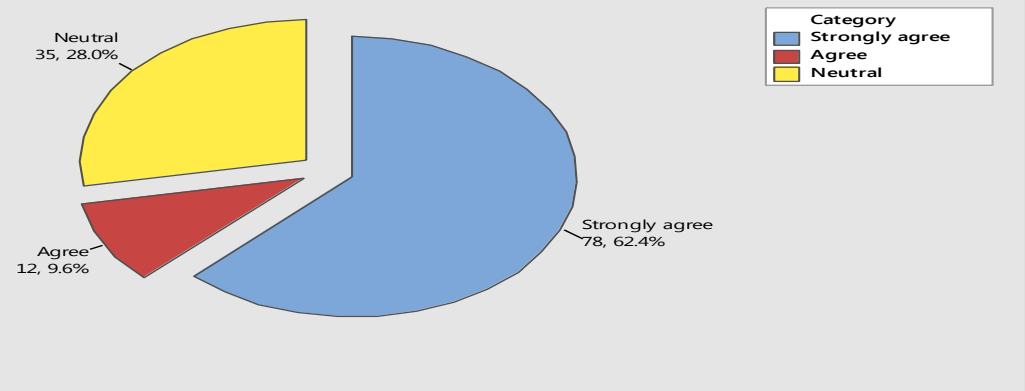

Figure (12): Satisfaction sense after group goal archived 


\section{Do you think it is important for group members to discuss the assignment with each other?}

$83.2 \%$ strongly agree, $12.8 \%$ agree and $4.0 \%$ neutral regarding the discussion of the assignment task with each other; this factor focused for the how much the members able to descried his/her experience between each other which all of the members have an experience any many filed can be useful by crossover and distribute the experience and this point cannot be effective unless if each member have an defined task and each one know what is the responsibility and the impact for each one.

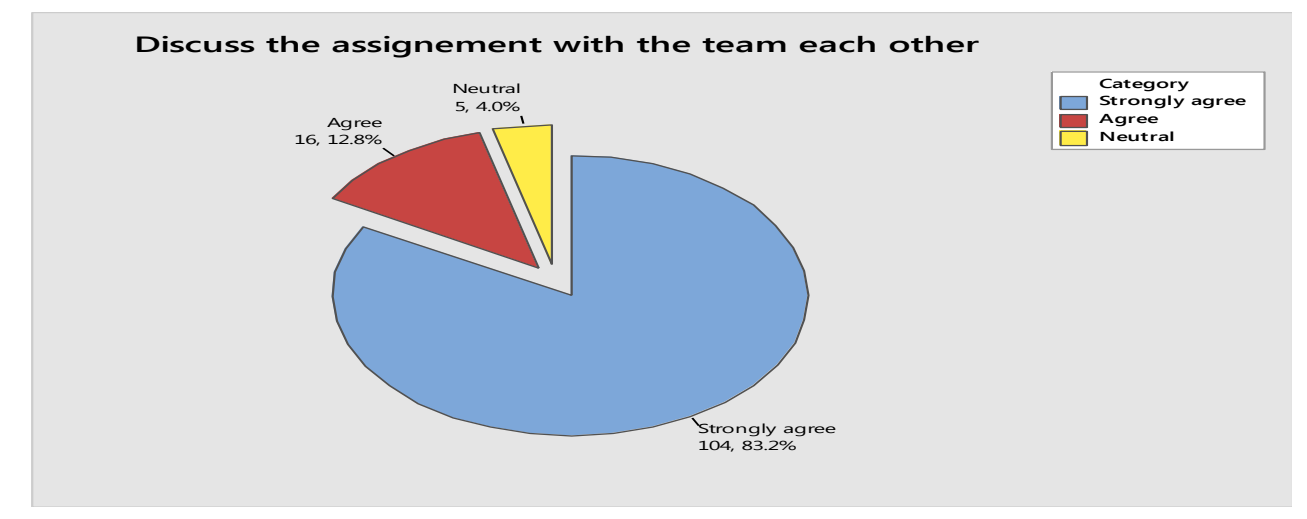

Figure (13): Discuss the assignment with the team each other

Feel like the workload is usually less if I were working alone.

$100 \%$ of the college assure that strongly agree that workload is usually less if work with group; this question can be assure that the group dynamic concept and importance of team building is believable and all of them ready to applying a systematic method to applying a framework to get a good team. 
Take every group member's ideas seriously is important factor for team building $79.2 \%$ strongly agree, $8.8 \%$ agree and $12 \%$ neutral; this factor have an impact for the importance of brainstorming between team member is a good practice for generate ideas and reflect a healthy environment between the group; also it's get a time saving during cases of problem solving.

Take every group member's ideas seriously is important factor for team building

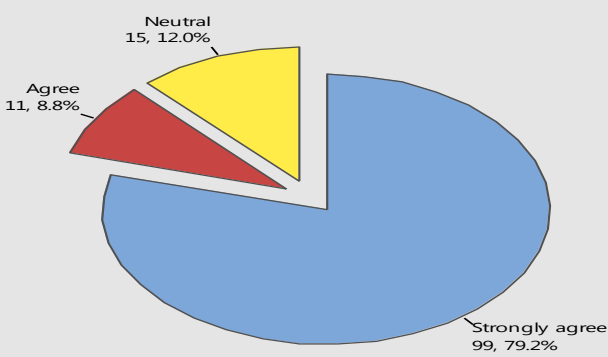

Figure (14): Brainstorming between team members

Do you think it is important for group members to take the time to listen to problems and worries of other group members?

$44 \%$ strongly agree, $28 \%$ agree, $16 \%$ neutral, $2.4 \%$ disagree and $9.6 \%$ disagree; this question target how to be benefit between cross over other groups which get an experience for recurrent case problem study's and save time for problem solving, brainstorming phases and create a preventive strategy for recurrent cases. 


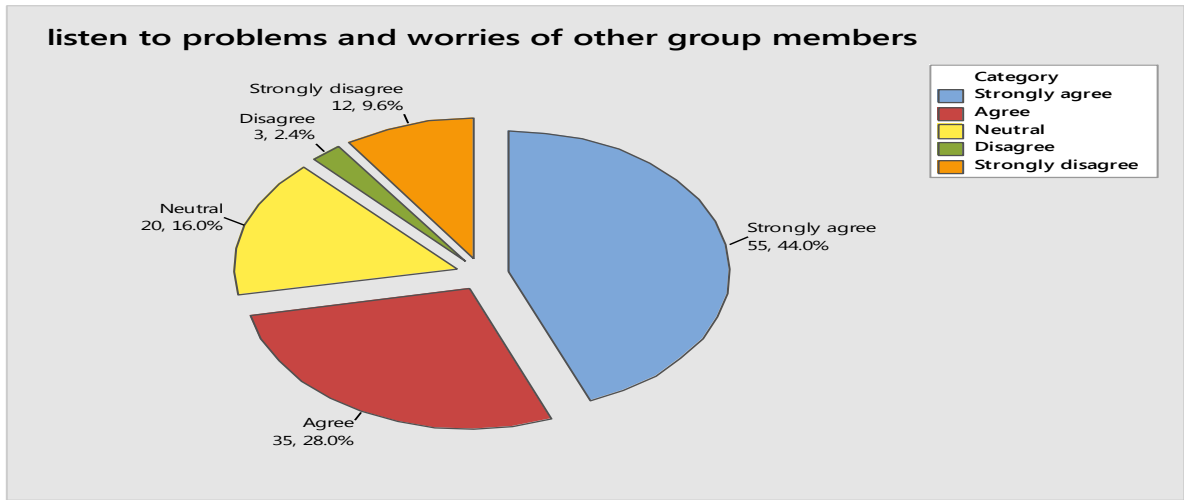

Figure (15): Listen to problems and worries of other group members

Making sure for group members have a highly homogenous for thinking is have a great value for success the team $96.8 \%$ strongly agree and $3.2 \%$ agree, by answering this question show that technique of selection the team members must be homogenous and highly interact with each other to be high impact and priorities the tasks and be on one way in thinking and on one mind set.

Figure (16): Homogeneity between the groups

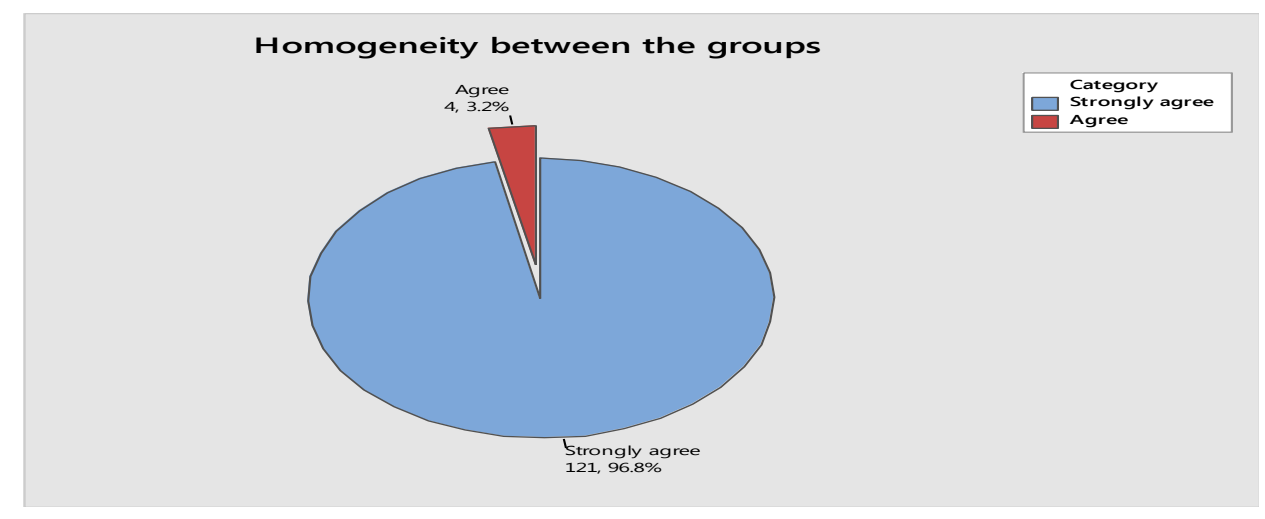

Figure (16): Homogeneity between the groups 
Share the ideas is highly Impact factor for build the group.

$88.8 \%$ strongly agree, $7.2 \%$ agree and $4 \%$ neutral; by collection of survey regrading this point appear that sharing knowledge between the groups is important which this was a very strong statement showing the importance of human resource in an organization. Hence it is very necessary to not only preserve your work force but also to keep them updated as well. Imagine, if the brain drains out what consequences could occur? It's very much important to share required knowledge with your co-workers. Organization should put emphasis on a culture of "Knowledge Sharing rather than Knowledge Hoarding."

Knowledge sharing plays a very vital role in creating awareness amongst the people in an organization. If things are properly shared, employees become aware about what is expected out of them and they can thus create a road map keeping in mind the availability of resources, its pros and cons and try to achieve better results for the company as well as clients and themselves.

\section{Do a fair share of the group's work in case of uncomfortable team?}

$53.6 \%$ strongly agree, $28.8 \%$ agree and $17.6 \%$ neutral, Resolving team conflict led to building strong teams by facing the differences; People have different viewpoints and, under the right set of circumstances, those differences escalate to conflict. How you handle that conflict determines whether it works to the team's advantage, or contributes to its demise.

Conflict isn't necessarily a bad thing, though. Healthy and constructive conflict is a component of high-functioning teams. Conflict arises from differences between people; the same differences that often make diverse 
teams more effective than those made up of people with similar experience. When people with varying viewpoints, experiences, skills, and opinions are tasked with a project or challenge, the combined effort can far surpass what any group of similar individual could achieve. Team members must be open to these differences and not let them rise into full-blown disputes.

When a team oversteps the mark of healthy difference of opinion, resolving conflict requires respect and patience. The human experience of conflict involves our emotions, perceptions, and actions; we experience it on all three levels, and we need to address all three levels to resolve it. We must replace the negative experiences with positive ones.

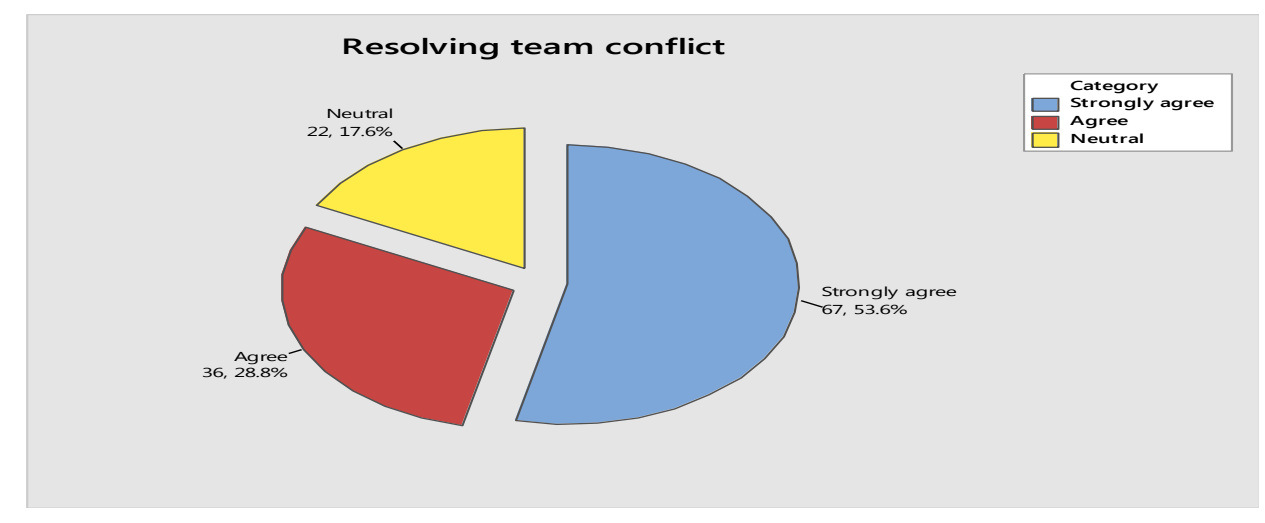

Figure (17): Resolving team conflict is an impact factor for build the group

Each of the above questions and fishbone diagram can be translated to the following factor to get systematic method to build a good team:

- Pre-work meeting or assessment

- Phasing any project to get a spot check for each project phase

- Identify the stockholders for each group

- Ideality the time actual and schedule one 
- Identify a team leader or group coach to assign and delegate the tasks to team members

- Generate a milestone to check the feasibility of the task and the group aim and target.

- Next chapter will get and display the systematic method can be gain the robust team.

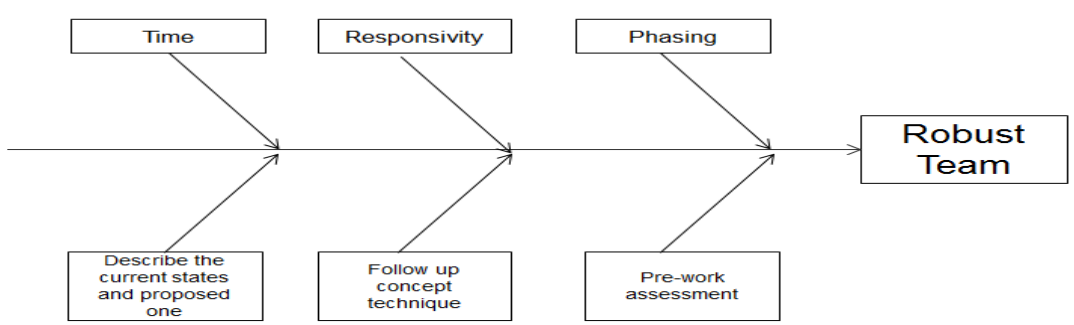

Figure (18): Fishbone diagram for get contributing factors for robust team

\section{Part 3:General rules for each project building:}

3.1. Pre-assessment meeting: A pre-assessment work has to be done before the decision to proceed and initiate the project taken; this pre-assessment work is under the lead of the project.

This assignment if the main and define the stakeholders has to be agreed to participate for the project.

The objective of this pre-work meeting is to have a preliminary discussion to clarify if the project should be initiated or not based on preliminary business case. 
And define the stakeholders, evaluate and implementation team and responsibilities clearly defined by the time line for each phase as an overall timeline and set up the action plan and milestones.

Any project must capture the reason or rational for this project, description of the current and proposed situation and any information needed to support a detailed evaluation.

3.2. Initiation and review the project scope: After the pre-work assessment step and selection the stockholders that will be participate during the project, the project lead must select a follow up person project coordinator that have a responsibility to review the progress and the get a reminder to members in the group.

Stakeholder planning and management continue during the initiation phase as the voice of the customer (VOC) and the voice of the associate assessments unfold. As the project environment is identified, the list of stakeholders may grow or be adjusted as the processes and dependencies are better defined and understood.

During initiation and reviewing phase the project lead must provide the project scope and rational for this project and describing the satiation before and after the project.

The objective of the initiation and reviewing phase is to pre-assess the impact of the project and prepare an evaluation plan based on the available information in order to achieve the approval for kicking off the evaluation phase. 
During the Define stage, focusing on sponsorship and understanding the view of stakeholders provides the foundation for the adoption work to come. Thus, the focus in the Sponsor and Understanding phases of the SUCCESS model is often rightfully on the sponsor - defining goals and success indicators. However, the earlier impacted stakeholders are involved, the more likely they will respond positively to the targeted change.

Involved stakeholders: Project lead, project coordinator, Project task manager; the project lead is the subject matter expert in the project to get an approval to move between phases.

3.3 Evaluation of the project based on a plan: The purpose of the evaluation phase is to evaluate the full impact of a project and the preparation of execution, authorization and implementation project plan, which contains the execution tasks and deliverables.

During evaluation phase the brainstorming between the group members of the group generate tasks for each stakeholder and define a schedule date for this task; after the stakeholder finalize his/her task must compare his schedule date and the actual date as adherence to the plan generated.

The project coordinators have a role during this phase to follow up the tasks between the group members and how much each one of them the timeline adhere.

Also have a privilege to make a reminder to stockholder to finalize the task before the due date.

The detailed work begins. Defining the target environment will undoubtedly reveal numerous stakeholder issues. Readiness for the target 
environment is one of these issues that will become the main focus of stakeholder planning.

An effective design concept developed during the Commit and evaluation phases considers critical stakeholder adoption issues during the early formation of the design work. At this time, sponsor and stakeholder commitment is assessed and critical system and process connections are identified. Ignoring adoption issues at this point creates what is later described as "theoretical rather than practical" solution designs that few stakeholders can adopt.

Impacted employees are more likely to commit to something they have been involved in creating from the beginning. These employees create excitement and commitment among their peers. Facilitated sessions focused on socializing and validating findings during the Measure phase are useful in engaging larger numbers of stakeholders and are an effective way of promoting adoption with employees and customers alike.

In the second part of the evaluation state the project task manager performs their tasks before the project coordinator perform the evaluation summary. The sub processes are the following:

Once the first phase passed the project task manager will perform their tasks with and without deliverables. The project coordinator will take the relevant information from tasks and populate evaluation summary which is relevant for creating the tailored execution plan. 
3.4. Execution of the project based on Execution plan: The execution plan is created and tailored upon the information from the evaluation summary.

The purpose of the execution phase is to timely and completely execute all tasks and sub-tasks and deliverables assigned to corresponding functional expert stakeholders which have been define as mandatory during evaluation and necessary to provide the required source documents for GMP documentation and/or registration preparation in case the project requires a submission.

Similar to the evaluation phase the assigned tasks are completed by the project task manager and review all tasks by the project coordinator to assure that all requirements needed for the project is prepared and in place; during this phase is like a preliminary for implementation phase.

The project coordinator assures feasibility of all resources to the project either human, budget and business need assessment for the project.

The importance of this phase is to save the time can be consumed during implementation phase which save the time and effort regarding preparation during the implementation the project.

Within the task the following tabs are included: General Information regarding the task required.

Schedule: which allow the member to manage the timeline for completion the task and show related subtask.

Dependencies: this tab in case of the task needs a prerequisite to be done; which in this case must be included in the timeframe matter. 
Team: this tab if the project task manager will use sub member to done the task required.

The practical concept defined in execution phase becomes a reality as detailed plans address not just the process or technology changes required but also the readiness issues of the stakeholders. Communications, training and transition planning are critical to employee and stakeholder readiness and often become the sole focus of stakeholder management during the execution phase. What is equally important though, are the management systems, policies and practices that will influence true sustainability long after the change managers and trainers are done. The connections identified during the Commit and Connect phases are further addressed.

It is at this time that management systems, compensation programs, recruiting and on-boarding practices, and other business elements also come into focus as key supporters or detractors of the target environment. Successful programs analyze these opportunities as part of the overall change effort rather than trying to address them afterward. This holistic approach addresses sustainable change before the program is transitioned to the business owner.

The impact of events targeted at enabling impacted stakeholders cannot be over-emphasized. Well-planned communication, training and support programs are critical to ensure that impacted stakeholders are successful in the targeted environment.

In one instance, a major real estate and relocation company embarked on an operations centralization and relocation effort. This change resulted in the closing of five regional offices, which led to significant employee 
terminations. The effectiveness of the communication and support programs, however, allowed them to retain key employees throughout the transition. The new location was staffed almost 80 percent with new employees, many without related experience. The company's success was directly attributed to effective communications with impacted associates and quality training programs.

\section{Implementations phase based on the plan:}

The purpose from implementation phase is to perform the tasks which be done the project by applying and completion this tasks.

The implementation tasks must be containing as well information about all requirements gain from evaluation and execution phase. The completion of the implementation tasks must be confirmed by the project lead.

During the implantations phase must be taken in the consideration from the project coordinator suitable time line to be sufficient to do tasks.

When processes and technologies are tested and validated. This is where change is translated to work functions, jobs and performance requirements. The same can be said of enabling strategies such as staff plans and training vehicles. Implementation plans receive final tweaks and controls are established.

Phase gate control between each phase describes the phases and the related tasks and deliverables are controlled by these gates. These gates ensure that all project plan tasks have been completed before gate for the next project phase. Ongoing tasks planning for the tasks and deliverable to be completed in upcoming phase of the process are determined in the preceding 
phase. Approval of the plan for upcoming phase forms a part of the activities that need to take place before the proceeding phase is closed and the project allowed proceeding.

3.5. Close- out phase: This phase to encompass the final and formal closure of the project. This phase generates the follow up tasks to insure the sustainability of the performance regarding the project or the change formed.

Any change to a process is only successful in the long run if the stakeholders truly adopt and sustain the change. Process and technology improvements cannot be implemented without a change in the hearts, minds and behaviors of the people involved in the change. True adoption and sustainability requires thoughtful planning and focus, which should be integral aspects of a Six Sigma deployment.

Traditional Six Sigma programs provide a disciplined and customerfocused method of improving business results, but sometimes lack the strategies and approaches that support stakeholder adoption and sustained change. Engagement and enablement needs to occur early on in the process, when stakeholders are still making up their minds about how they feel about the change. Yet many programs rely on a communication system developed late in the game. As a result, project plans typically address stakeholder issues long after impacted employees and customers have decided whether or not they will buy into the change.

Sustaining change and building stakeholder engagement follows a model, known by the acronym SUCCESS, which stands for sponsor, understand, commit, connect, enable, support and sustain. These steps share similar tools 
and approaches used in the traditional DMAIC framework and can be aligned roughly with the phases of Define, Measure, Analyze, Improve and Control. During close-out phase - stakeholders are migrated to the target environment. Support programs, such as training and communications, are completed. The project is implemented and controls are validated. New requirements are reflected in performance scorecards, metrics and dashboards to monitor and sustain the target environment. Process changes are transitioned to business and process owners. The target environment is considered "business as usual" and the project is closed out.

As the project is closed out, a key component of sustaining change is the recognition and reward of contributors and the celebration of successes. Recognition and celebration are key contributors to sustainability, yet they may be overlooked in the haste to reach the goal line and close out the work. Sustain ensures that recognition is given to motivate those who have truly adopted the changes and to entice those who continue to resist.

\subsection{Responsibilities:}

Project Coordinator Role: The project coordinator role is the important roles in the system which must be have a good communication and leadership skills to be able to manage and coordinate the whole project.

Previous experience in cooperating with Project Managers for the delivery of projects; Solid organizational skills including attention to detail and multitasking skills 
A project coordinator plays a temporary but crucial role in managing the team and plans the execution of all the tasks needed to create a product / service according to the time, budget and quality criteria.

The ability to listen, in fact, is another very important strength because, a project manager who is also able to listen carefully, can monitor and control the entire project more efficiently.

In addition, understanding and managing in the right ways the expectations of all the stakeholders, going deeper about the everyday job done by the allocated resources, knowing exactly the final result of the project rather than every single development's detail, reporting any requirement's change and quickly prompting for any possible outstanding problems, are all important qualities that a good project manager should possess.

Project Coordinator who will run, administer and organize all project activities in cooperation with and under the direction of the Project Manager, aiming at the flawless execution of the project.

The project coordinator will invites the stakeholders to the pre-work meeting and crate the tasks during the system phases.

The project coordinator responsible to assign tasks owner and reviewers according to the pre-work assessment and review in the first phase initiate and review phase.

Also he is responsible to make the evaluation summary foe the seconded phase as the impact of the project and get the criticalities and what is the needed to be prepared to next phase. 
Coordinate activities, resources, equipment and information. Liaise with the client if internal or external client to identify the project requirement, scope and objectives.

Monitor and track project progress and handle any issues that arise; act a point of contact and communicate project status adequately to all participants. Use project management tools to monitor working hours, budget, plans and money spend.

Create and maintain comprehensive project documentation, plans and reports.

Project Task manager Role: The project task manager is responsible for the completion of assigned tasks and deliverable in the project.

Assure that the time assigned to the project task manager is feasible to do the task; also assure that all resources are available.

Sharing the information and experience between the project task managers is the most useful way to success the project task managers and make good and rubostance team.

Project Leader Role: The project leader Role is to approve and review the millstone during the project life which acts like gate approval to move to next step by step.

The first approval is for kick off the project after pre-work meeting and set the objectives and the tasks description by the each participant role profile and experience.

Making sure that all timeline is feasible based on his or her experience; also the project coordinator take the description to the way of follow up from 
the project leader and the project leader is act like escalation procedure in any case issue like for example passing the due date from one of the project task managers.

Approving for the tasks assignation in the evaluation, execution and close out phase.

Reviewing the close-out phase to assure that the follow up tasks generated to assure the sustainability for the project or task.

\section{CONCLUSION}

This thesis has investigated whether the use of group dynamic techniques and project management concepts with information technology has a positive effect on team building, project enhancement and time management.

The researcher's starting out his research by two questions: What potential resistances might be faced during the implementation of team building strategy "group dynamic"?

How can leaders practice team building strategy to get a maximum performance in work?

The research concern on his research to prove or disprove the systematic way to build team based on several achievements on the ground an collect the feedback and information for group build to get the systematic an effective way for team building.

The final project dissection have shown that there are a significate enhancement in the quality central compliance department for building the group for several projects 
As a recommendation for the future work, can implement the systematic group build in several sectors not only the pharmaceutical sectors but in different sector which like a role model can applying by phasing technique.

\section{REFERENCES}

Ashford, J. B. (2010.2008): Human behavior in Social Enviroment. United States: Wadsworth, Cengage Learning.

Bolden, R., Gosling, J., Marturano, A. and Dennison, P.(June 2003): A Review Of Leadership Theory And Competency Frameworks.

Badaway, M.K. (1982): Developing Managerial Skills in Engineers and Scientists, New York: Van Nostrand Reinhold.

Backstrom, L., Huttenenlocher, D., Kleinberg, J., \& Lan, X. (2006): Group formation in large social networks. ACM AIGKDD international confrtrnce on Knowledge discovery and data mining - KDD, 44.

Backstrom, L., Huttenenlocher, D., Kleinberg, J., \& Lan, X. (2006): Group formation in large social networks. ACM AIGKDD international confrtrnce on Knowledge discovery and data mining - KDD, 44.

Carter, J. (2007): Leadership the outward bound way. United States of America: The Mauntaineers Book.

Chatfield, R. (1965): Leadership the Outward Bound Way: Becoming a Better Leader in the Workplace. USA.

Eden, D. (1985, Feb):. Team Development:Atrue field expiment at three levels of rigor. pp. 94-100.

Einsiedel, A.A., Jr. (1987): Profile of effective project managers, Project Management Journal, pp. 51-56.

FME, T. (2013):. Principle of Team Buliding. International and Federal Laws and traties.

Forsyth, D. R. (1900): Group dynamic .

Forsyth, D. R. (Mar 19.2009): Group dynamic. 
Fapohunda, T. M. (2013): Towards Effective Team Buliding in thr Workplace. International Journal of Education and Research.

Geneva. (2007): Team Building. World Health Organization WHO, 4-5.

Hogg, M. A. (June 2004):. The Social Identity Perspective Intergroup Relations, Self-Conception and Small Group. University of Queensland, Australia.

Holly Arrow, J. E. (2000):Small Groups as Complex systems. United kingdom: Sage Publications, Inc.

Kloppenborg, T. J., \& Petrick, J. A. (1999): Leadership In Project Life Cycle $\&$ Team Character Development, Project • Management Journal, 30(2), p. 8.

Kumar, Sameer, and Promma Phrommathed. Research methodology. Springer US, 2005.

Kumar, S., \& Phrommathed, P. (2005): Research methodology (pp. 43-50). Springer US.

KUMAR, Sameer; PHROMMATHED, Promma. Research methodology. Springer US, 2005.

Langrfred, C. W. (2007): The Downside of self Managment . Academy of Management Journal.

Lwin, K. (1951): A Study of Group Dynamics and its Possible Negative Implications sweetbread study. Bulletin of the National Research Council.

M. Scott Peck, M. (1987): A Spiritual Journey Tward Self Acceptance, True Belonging, and New Hope for the Word. In M. M. Scott Peck, The Different Drum (pp. 95-103). United States of America: TOUCHSTONE.

N. John Castellan, J. (1993): Individual and Group Decision Making: Current Issues. In J. N. John Castellan, N. John Castellan, JR (pp. 226228).

Nazzaro, A.-M. (2009): Group Dynamics And Team Building. 2003: The World Federation of Hemophilia (WFH). 
(2008). building shared mental models. In W. G. Piet Van den Bossche, Instructional Science (p. 25). Instructional Science.

(2005). the Theory and Practice of Group Psychotherapy. In M. L. Irvin D. Yalom, The Theory and Practice of Group Psychotherapy (pp. 194-196). New York NY : Basic Books; A Member of the Perseus Group.

Pinto, J. K., \& Thoms, P. (1999): Project leadership: A question of timing. Project Management Journal, 3(1).

Reddin, B. (1988): The output oriented organization, Gower publishing company limited, p.73.

Robinson, G. \& Robinson, S. (1994): Notes and handouts for project management course sponsored by the School of Journal of Project Management

Sadava, J. A. (2014): An Introduction to Social Pyschology. Los angeles; London; New Delhi; Singapore: SAGE.

Salas, E. D. (2008): Dose Team Training Improve Team Performance A Meta-Analysis. Human Factors; The Jornal of the Human Factors and Eronomics Society, 50-62.

Salas, E. D. (n.d.). Dose Team Training Improve Team Performance A MEta.

Team Building through Mutual Sharing and Open Discussion of Team Functioning. (2009). The Sport Psychologist, human kinetics, Inc, 523.

Tuckman, B. (1965): Team Development Model. Culture Artwork.

Tuckman, B. W. (1965): Developmental Sequence in Small Group.

Tuckman, B. W. (1965): Developmental sequence in small groups. In B. W. Tuckman, Developmental sequence in small groups (pp. 384399). Psychological Bulletin.

Thamhain, H.J. (1988): Team Building in Project Management, Project Management Handbook, Second Edition, Eds.

Westheimer, G. (1998): Gestalt theory reconfigured:Max Wertheimer's anticipation of recent developments in visual neurosience. 
Berkeley USA: Division of Nurobiology Univiersity of Calofornia.

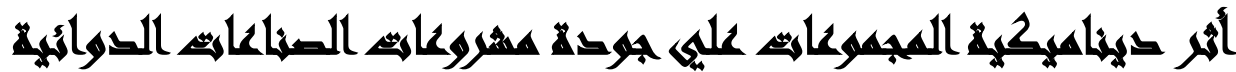

\section{[ध]}

نبيل الضبع|(')- أحمد (براهيم بهجت السداوي(')-- محمد حسن أحمد

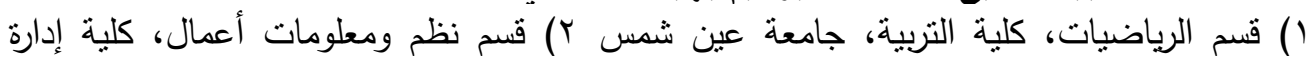

الاعمال، الاكاديمية العربية للعلوم والتكنولوجيا ب) الاكاديمية العربية للعلوم والتكنولوجيا

\section{(1)}

ديناميكية المجموعة وإدارة المشاريع تعتبر على حد سواء من اهم التطبيقات باعتبارها جزءا من

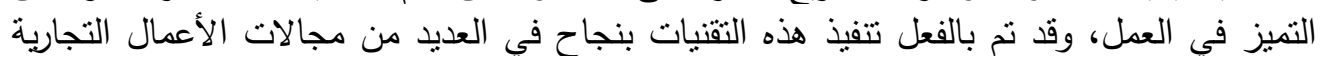

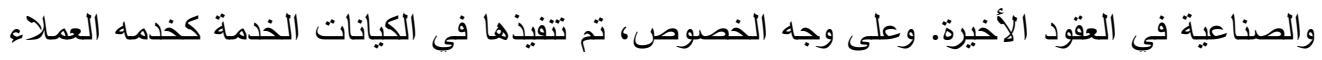

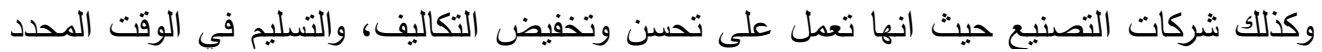
كافه الاعمال والمهام بالجودة المطلوبة للمشروع.

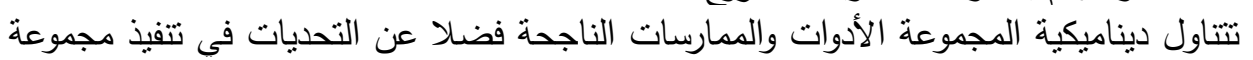
ديناميكية تتكامل مع تقنيات إدارة المشاريع عن طريق اتباع إدارة المشروع ومجموعة منهجية استخدام الأدوات المناسبة في كل مرحلة، تعمل على تسريع التقدم المحرز في المشروع إلى ديناميكية. تحقيق الأهداف والأهداف المقترحة بطريقة عملية. يهدف الباحث الى تكوين نظام يهدف الى تحسين العمليات و طرق التطبيقات من خلال منهجية

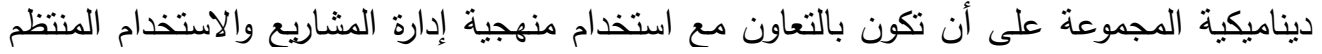

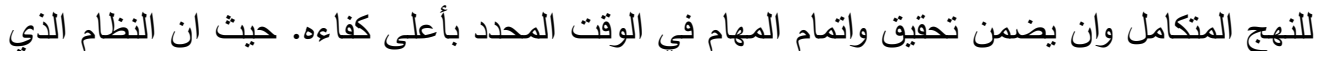

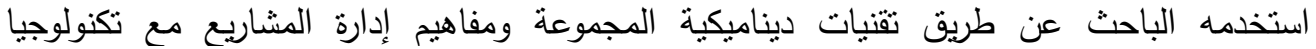
المعلومات له نأثثر إيجابى على بناء فريق، وتعزيز المشاريع وادارة الوقت.

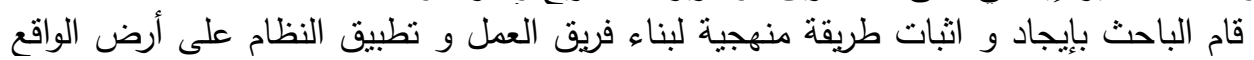

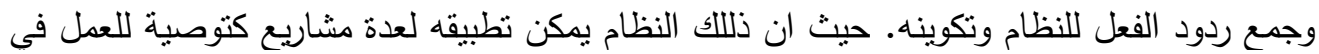
المستقبل على اساس شموليه علم الجودة.

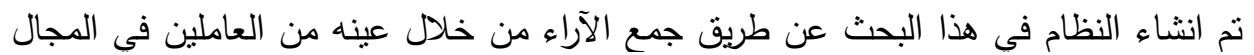
الصناعي و تحليل هذه الاجابات احصائيا و نرجمنها وصولا الي النظاء من النظام المبتكر في البحث. 
J. Environ. Sci.

Institute of Environmental Studies and Research - Ain Shams University

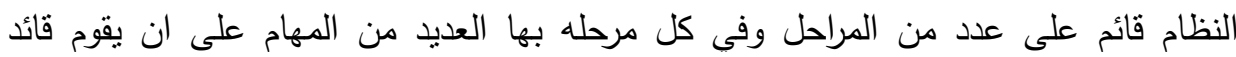

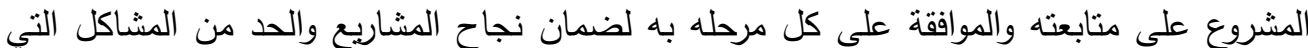

يمكن مواجهتها خلال تطبيق المشاريع. 